\title{
A Bayesian change-point algorithm for detecting copy number alteration
}

\author{
Fridtjof Thomas ${ }^{1 *}$, Stanley Pounds ${ }^{2}$ \\ From UT-ORNL-KBRIN Bioinformatics Summit 2010 \\ Cadiz, KY, USA. 19-21 March 2010
}

\section{Background}

Recent technical developments have made it possible to collect high-resolution genomics data using single nucleotide polymorphism (SNP) arrays. These arrays can be used in a paired data context to compare cancer tissue to normal samples in an effort to identify regions of genomic amplification or deletion. Such regions potentially contain oncogenes or tumor suppressor genes and are therefore of particular interest. However, using SNP array signals to identifying regions of copy number alteration is a challenging task due to the properties of the derived measurements.

\section{Materials and methods}

We apply a Bayesian change-point algorithm to pre-normalized signals from SNP microarrays obtained from a set of leukemia samples in an effort to infer regions of copy number alteration and compare this approach to other approaches currently in use for this purpose.

The Bayesian change-point algorithm detects multiple change-points where a change can be in the mean of the subsequent measurements, in their variance, in their autocorrelation structure, or in a combination of two or all of these aspects.

\section{Author details}

${ }^{1}$ Department of Preventive Medicine, University of Tennessee Health Science Center, Memphis, TN 38105, USA. ²Department of Biostatistics, St. Jude Children's Research Hospital, Memphis, TN 38105, USA.

Published: 23 July 2010

doi:10.1186/1471-2105-11-S4-P17

Cite this article as: Thomas and Pounds: A Bayesian change-point algorithm for detecting copy number alteration. BMC Bioinformatics 2010 11(Suppl 4):P17.

\footnotetext{
* Correspondence: fthomas4@uthsc.edu

${ }^{1}$ Department of Preventive Medicine, University of Tennessee Health Science Center, Memphis, TN 38105, USA
}

Submit your next manuscript to BioMed Central and take full advantage of:

- Convenient online submission

- Thorough peer review

- No space constraints or color figure charges

- Immediate publication on acceptance

- Inclusion in PubMed, CAS, Scopus and Google Scholar

- Research which is freely available for redistribution

Submit your manuscript at www.biomedcentral.com/submit
C) Biomed Central 